\title{
Journal of Computer and Education Research
}

December 2017 Volume 5 Issue 10

www.joucer.com

http://dergipark.gov.tr/jcer

Araştırma Makalesi

\section{Investigation of Science Teachers' Learning Styles with Various}

\section{Variables}

\author{
Orhan KARAMUSTAFAOĞLU1*iD, Miyase TUTAR² (D) , Gökhan SONTAY3D \\ ${ }^{1}$ Amasya Üniversitesi, Eğitim Fakültesi, Matematik ve Fen Bilimleri Eğitimi Bölümü, orhan.karamustafaoglu@amasya.edu.tr \\ ${ }^{2}$ Amasya Üniversitesi, Fen Bilimleri Enstitüsü, Matematik ve Fen Bilimleri Ĕ̆g. ABD, miyasetutar@gmail.com,gokhansontay@gmail.com \\ ${ }^{3}$ Amasya Üniversitesi, Fen Bilimleri Enstitüsü, Matematik ve Fen Bilimleri Ĕ̆g. ABD, gokhansontay@gmail.com \\ *Corresponding Author: orhan.karamustafaoglu@amasya.edu.tr
}

Article Info Abstract

Received: $\quad$ March 17, 2017

Accepted: $\quad$ August 03, 2017

Online: $\quad$ December 03, 2017

Keywords: Learning Styles, Felder and Soloman learning inventory, science teacher candidates

\begin{abstract}
It was aimed to determine learning styles according to Felder Silverman learning styles and to examine various variables in this research. The study was carried out through a descriptive design involving a survey model with a sample of 322 science student teachers studying at Amasya Faculty of Education on during 2016-2017 academic years. The "Learning Style Inventory" developed by Felder \& Soloman (1994) and adapted to the Turkish language was used as a data collection tool. Data were analyzed using independent t-test and one-way analysis of variance (ANOVA). As a result of the research, it was determined that science teacher candidates had visual and sequential learning styles by doing, feeling, and doing. The highest score from the learning styles that the teacher candidates possessed was the visual learning style. In addition, learning styles differed according to gender, grade level and father education status in the survey. Based on the results of the research, necessary suggestions were made.
\end{abstract}

To cite this article: Karamustafaoğlu, O., Tutar, M. \& Sontay, G. (2017). Fen bilimleri öğretmen adaylarının öğrenme stillerinin çeşitli değişkenlerle incelenmesi. Journal of Computer and Education Research, 5 (10), 255-280. https://doi.org/10.18009/jcer.298669

\section{Fen Bilimleri Öğretmen Adaylarının Öğrenme Stillerinin Çeşitli Değişkenlerle İncelenmesi}

\begin{tabular}{|c|c|}
\hline Makale Bilgisi & $\ddot{O ̈ z}$ \\
\hline $\begin{array}{l}\text { Geliş: } \quad \text { 17 Mart } 2017 \\
\text { Kabul: } \quad \text { 03 Ă̆ustos } 2017 \\
\text { Yayın: } \quad \text { 03 Aralık } 2017 \\
\text { Anahtar kelimeler: Öğrenme stilleri, } \\
\text { Felder ve Soloman öğrenme stili } \\
\text { envanteri, fen bilgisi öğretmen } \\
\text { adayları }\end{array}$ & $\begin{array}{l}\text { Araştırmada fen bilimleri öğretmen adaylarının Felder Silverman öğrenme } \\
\text { stillerine göre öğrenme stillerinin belirlenmesi ve çeşitli değişkenler yönüyle } \\
\text { incelenmesi amaçlanmıştır. Araştırma betimsel tarama modeli kapsamında } \\
\text { yürütülmüş olup araştırmanın örneklemini bir eğitim fakültesinde öğrenim } \\
\text { görmekte olan } 322 \text { fen bilgisi öğretmen adayı oluşturmaktadır. Felder ve } \\
\text { Soloman (1994) tarafından geliştirilen ve Türkçeye uyarlanan "Öğrenme Stili } \\
\text { Envanteri" veri toplama aracı olarak kullanılmıstır. Verilerin analizi bağımsız t- } \\
\text { testi ve tek yönlü varyans analizi (ANOVA) kullanılarak yapılmıştır. Araştırma } \\
\text { sonucunda, fen öğretmen adaylarının yaparak, hissederek, görsel ve sıralı öğrenme } \\
\text { stillerine sahip oldukları tespit edilmiştir. Öğretmen adaylarının sahip oldukları } \\
\text { öğrenme stillerinden en yüksek skoru görsel öğrenme stili almıştır. Ayrıca } \\
\text { araştırmada cinsiyet, sınıf seviyesi ve baba eğitim durumlarına göre öğrenme } \\
\text { stilleri farklılık göstermiştir. Araştırma sonuçlarına dayanarak ilgililere gerekli } \\
\text { önerilerde bulunulmuştur. }\end{array}$ \\
\hline
\end{tabular}




\section{Journal of Computer and Education Research}

December 2017 Volume 5 Issue 10

www.joucer.com

http://dergipark.gov.tr/jcer

Summary

\section{Investigation of Science Teachers' Learning Styles with Various Variables}

\section{Introduction}

When the literature is examined, it is seen that many researches about the learning styles of the individuals have been made and different learning styles have been determined in this direction (Şeker Sır, Karataş \& Çeliköz, 2015; Güneş \& Gökçek, 2012; Fer, 2003). There are different approaches to defining learning styles. The reason for the differences in these approaches is the focus on different domains such as cognitive, emotional and psychomotor. Learning style models in which the cognitive domain taken into consideration are Kolb, McCarthy and Gregorc; The learning style models in which the affective domain taken into consideration are Silver and Hanson, Dunn and Dunn and Curry; Learning style models that take into account the psychomotor domain are Silver and Hanson, Dunn and Dunn and Curry learning styles (Ekici, 2001). Felder and Silverman Learning Style Model is another learning style model that was introduced in 1996. According to Felder and Silverman, learning occurs in a two-step process; Taking the first step information, and the second step processing the received information. Knowledge (internally sourced) taken from the outside world through the sensory organs (outsourced) or through internal observation is still available to the student at the step of taking the information. The step of processing information involves processes such as simply keeping in mind, making inductive or deductive reasoning, reflection or activity, self-analysis (Felder \& Silverman, 1988).

Once the learning styles of the individuals are determined, it is easier to estimate how these individuals will learn and how they can apply to instructional design (Babadoğan, 2000). Therefore, the identification of individual learning styles is important for the realization of permanent learning. Individuals with multiple learning styles can be found in any classroom environment. Teacher candidates studying at university also have their own 
learning styles. Determination of these learning styles will benefit training professionals with qualified teachers.

Therefore, in this study, it was aimed to determine the learning styles of science teacher candidates and to examine them in terms of different variables. The main problem of the research is that the learning styles of science teachers are different according to what the learning styles are and some variables.

The research was carried out a descriptive research design as a survey model and the sample of the research is consists of 322 science teacher candidates studying at a faculty of education. The "Learning Style Inventory" developed by Felder and Soloman (1994) and adapted to the Turkish language was used as a data collection tool. Data were analyzed using independent t-test and one-way analysis of variance (ANOVA). As a result of the research, it was determined that science teacher candidates had visual and sequential learning styles by feeling, and doing. The highest score from the learning styles that the teacher candidates possessed was the visual learning style. In addition, learning styles differed according to gender, grade level and father education status in the survey. Based on the results of the research, necessary suggestions were made. 


\section{Giriş}

Öğrenme, bireyin karşılaştığı bilgiyi kendi zihninde yapılandırmasıyla gerçekleşmektedir. Öğrenmede bireylerin zihinsel faaliyetleri önemli olduğundan öğretim sürecinde bireyin bilgiyi nasıl algılayıp işlediğinin bilinmesi önemlidir. Etkili bir öğrenme, bireyin sahip olduğu öğrenme stili doğrultusunda hazırlanmış eğitim programlarının uygulanmasıyla sağlanabilir (Kaya ve Akçin, 2002). Öğrenme stili ile ilgili 1960 yılında ilk olarak Rita Dunn tarafından bir tanım yapılmakla birlikte (Güven, 2004) daha sonraki yıllarda birçok araştırmacı tarafından farklı tanımlar yapılmıştır. Dunn ve Dunn (1986) öğrenme stilini “bireyin öğrenmeye yönelik tercihleri” olarak tanımlarken; Mumford (1987) “öğrenenin öğrenme sürecindeki ve öğrenme etkinliklerindeki tercihleri” olarak tanımlamıştır. Ayrıca Felder ve Silverman (1988)'da öğrenme stilini “bireylerin bilgiyi alma, tutma ve işleme sürecindeki karakteristik güçlülük ve tercihler" olarak tanımlamıştır. Bireylerin sahip oldukları öğrenme stilleri birbirine benzer olabildiği gibi birbirlerinden çok farklı da olabilmektedir. Bu yüzden okul ortamlarında her bir öğrenci için farklı bir öğrenme ortamı tasarlamak mümkün olmayabilir (Yılmaz ve Özgür, 2012). Bu durumda karşılaşılabilecek problemlerin önlenmesi için farklı bireysel stillere yönelik zengin öğrenme materyallerin bulunduğu öğrenme ortamları oluşturulabilir (Erden \& Altun, 2006). Bu bağlamda eğitmenler, öğrencilerin öğrenme stillerini dikkate alarak, tamamlayıcı ortamlar hazırlayarak onların daha iyi öğrenmesini destekleyen bir yapıda öğretim verebilirler (Schunk, 2009). Dwyer (1996) ise çalışmasında, hangi öğrenme ortamında olunursa olunsun, öğrencilerin öğrenme stillerinin dikkate alınarak sürecin tasarlanması gerektiğini vurgulamaktadır (Kılıç \& Karadeniz, 2004).

Literatür incelendiğinde bireylerin öğrenme stilleri ile ilgili birçok araştırmalar yapıldığı ve bu doğrultuda farklı öğrenme stillerinin belirlendiği görülmektedir (Şeker Sır, Karataş \& Çeliköz, 2015; Güneş \& Gökçek, 2012; Köse, 2010; Demir, 2008; Fer, 2003). Öğrenme stillerinin tanımlanmasında farklı yaklaşımlar bulunmaktadır. Bu yaklaşımlardaki farklılığın sebebi, öğrenmenin farklı boyutları (bilişsel, duyuşsal ve devinişsel) üzerinde odaklanılmasıdır. Bilişsel boyutun dikkate alındığı öğrenme stili modellerine Kolb, McCarthy ve Gregorc; duyuşsal boyutun dikkate alındığı öğrenme stili modellerine Silver ve Hanson, Dunn ve Dunn ile Curry; fizyolojik boyutun dikkate alındığı öğrenme stili modellerine ise Silver ve Hanson, Dunn ve Dunn ile Curry öğrenme stilleri örnek olarak verilebilir (Ekici, 2001). Felder ve Silverman Öğrenme Stili Modeli ise 1996 yılında ortaya 
konan bir diğer öğrenme stili modelidir. Felder ve Silverman'a göre öğrenme iki basamaklı bir süreçte gerçekleşir; ilk basamak bilginin alınmasını, ikinci basamak ise alınan bilginin işlenmesini içerir. Bilginin alınması basamağında dış dünyadan duyu organları ile alınan (dış kaynaklı) ya da iç gözlem yoluyla ortaya çıkarılan (iç kaynaklı) bilgi, öğrenci tarafından alınabilir hâle gelir. Bilgiyi işleme basamağı ise, basit olarak akılda tutma, tümevarım ya da tümdengelim muhakeme yapma, yansitma ya da etkinlikte bulunma, kendi kendine tahlilde bulunma gibi süreçleri içerir (Felder \& Silverman, 1988). Bir öğrencinin öğrenme stili, beş soruya verilen cevaplarla tanimlanabilir (Felder \& Silverman 1988; Felder \& Henriques, 1995):

1. Öğrenciler, hangi tür bilgiyi algılamayı tercih ederler? : Duyusal - sezgisel

2. Öğrenciler, hangi duyusal kanal aracılığı ile bilgiyi etkili bir şekilde içselleştirirler? : Görsel - işitsel

3. Öğrenciler, bilginin hangi düzende verilmesi ile daha rahat kavrarlar? : Tümevarım tümdengelim

4. Öğrenciler bilgiyi nasıl işlemeyi tercih ederler? : Aktif-yansıtıcı

5. Öğrenciler kavramalarını nasıl gerçekleştiriyorlar? : Analitik-bütünsel

Felder ve Silverman (1988) öğrenme stilli modeli üzerinde bazı değişiklikler yaparak modeli revize etmişlerdir. Öğrenme stillerini hissederek-sezgisel, görsel-işitsel, yaparak-düşünerek ve bütünsel-sıralı olacak şekilde dört alt boyuta ayırmışlardır. Felder ve Silverman (1988)'a göre öğrenme stillerine sahip bireylerin sahip oldukları özellikler aşağıdaki şekilde ifade edilmiştir:

- Hissederek veya sezgisel öğrenme stillerine sahip bireylerin bilgiyi alma açısından farklılaşmaktadırlar. Duyu organlarına gelen bilgiyi daha iyi algılayan bireyler hissederek, hafızalarından, düşüncelerinde ve hayal güçlerinden gelen bilgiyi daha iyi algılayan bireyler ise sezgisel öğrenme stiline sahiptir.

- Görsel ve işitsel öğrenme stili, bireylerin bilgiyi almada hangi duyu organını tercih ettiğine göre değişim göstermektedir. Görsel öğrenen bireyler bilginin şekiller, şemalar ve gösteriler gibi görsel unsurlarla verilmesini tercih ederken işitsel öğrenenler sözlü metinleri, açıklamaları tercih etmektedirler.

- Yaparak ve düşünerek öğrenen bireyler, bilginin alındıktan sonra yapılandırılmasında farklılaşmaktadırlar. Yaparak öğrenenler bilginin test etme, açıklama, 
tartışma gibi eylemlerde bulunurken düşünerek öğrenenler kendi kendilerine düşünerek mukayese etme eğilimi göstermektedirler.

- Bütünsel ve sıralı öğrenenler bilgiyi alma yönünden farklılık göstermektedirler. Bütünsel öğrenen bireyler ilk olarak konunun genelini öğrenmeye odaklanırlar ve aldıkları bilgiyi sahip oldukları bilgilerle ilişkilendirmeye çalışırlar. Sıralı öğrenen bireyler ise bilgiyi ayrı olarak alırlar ve bilgiyi daha detaylı olarak öğrenmeyi tercih ederler.

Bireylerin sahip oldukları öğrenme stilleri belirlenirse, bu bireylerin nasıl öğrenebileceği ve onlara nasıl bir öğretim tasarımı uygulanabileceği daha kolay bir biçimde kestirilebilir (Babadoğan, 2000). Bu yüzden bireylerin öğrenme stillerinin belirlenmesi kalıcı öğrenmenin gerçekleşmesi için önem arz etmektedir. Herhangi bir sınıf ortamında birden farklı öğrenme stillerine sahip bireyler bulunabilmektedir (Peker, Mirasyedioğlu \& Aydın, 2004). Üniversitede öğrenim gören öğretmen adaylarının da kendilerine özgü öğrenme stilleri bulunmaktadır. Bu öğrenme stillerinin belirlenmesi nitelikli öğretmen yetiştirmede eğitim uzmanlarına fayda sağlayacaktır. Dolayısıyla bu çalışmada Fen Bilgisi öğretmen adaylarının öğrenme stillerinin belirlenmesi ve farklı değişkenler açısından incelenmesi amaçlanmıştır. Araştırmanın temel problemi, Fen Bilimleri öğretmen adaylarının öğrenme stillerinin neler olduğu ve bazı değişkenlere göre farklılaşıp farklılaşmadığıdır.

Çalışmada aşağıdaki alt problem durumlarına cevap aranmıştır:

1. Fen Bilgisi öğretmen adaylarının öğrenme stilleri nelerdir?

2. Fen Bilgisi öğretmen adaylarının öğrenme stilleri demografik özelliklere (cinsiyet, sınıf seviyesi, mezun olduğu okul türü vb.) göre değişim göstermekte midir?

\section{Yöntem}

Çalışma öğretmen adaylarının öğrenme stillerinin belirlenmesinden dolayı betimsel tarama modelinde yürütülmüştür. Betimsel tarama modelinde var olan durumun tespit edilmesi amaçlanmaktadır. Tarama modelleri, geçmişte ya da halen var olan bir durumu var olduğu şekliyle betimlemeyi amaçlayan araştırma yaklaşımlarıdır. Araştırmaya konu olan olay, birey ya da nesne, kendi koşulları içinde ve olduğu gibi tanımlanmaya çalışılır. Onları herhangi bir şekilde etkileme ya da değiştirme çabası yoktur. Önemli olan var olanı var olduğu şekliyle betimleyebilmektir (Karasar, 2006).

Örneklem

Çalışmanın örneklemini Amasya Üniversitesi Eğitim Fakültesi'nde öğrenim görmekte olan 322 Fen Bilgisi öğretmen adayı oluşturmaktadır. Araştırmaya 2016-2017 
eğitim-öğretim yılında öğrenim gören 337 öğretmen adayı katılmıştır. Öğretmen adaylarının cevaplandırdığı envanterlerin bazı bölümlerinin eksik olmasından dolayı 15 veri çıkartılmış ve araştırmada 322 öğretmen adayından alınan veriler kullanılmıştır. Tablo 1'de araştırmaya katılan öğretmen adaylarının cinsiyet ve sınıf durumlarına göre dağılımları verilmiştir.

Tablo 1. Örneklem grubunun cinsiyet ve sınıf durumuna göre dağılımı

\begin{tabular}{cccc}
\hline & Gruplar & Frekans (F) & Yüzde (\%) \\
\hline \multirow{2}{*}{ Cinsiyet } & Kadın & 245 & 76,1 \\
\cline { 2 - 4 } & Erkek & 77 & 23,9 \\
\hline \multirow{3}{*}{ Sinıf Düzeyi } & 1. Sınıf & 87 & 27,0 \\
\cline { 2 - 4 } & 2. Sinıf & 81 & 25,2 \\
\cline { 2 - 4 } & 3. Sınıf & 77 & 23,9 \\
\cline { 2 - 4 } & 4. Sınıf & 77 & 23,9 \\
\hline
\end{tabular}

Veri Toplama Araci

$\mathrm{Bu}$ araştırmada, veri toplama aracı olarak; Felder ve Soloman (1994) tarafından geliştirilen ve Samancı ve Keskin (2007) tarafından Türkçe’ye uyarlanan “Öğrenme Stili Envanteri" kullanılmıştır. Envanter Felder ve Silverman'ın (1988) 4 boyut içeren öğrenme stili modeline göre hazırlanmıştır. Bu boyutlar, yaparak/düşünerek, hissederek/sezgisel, görsel/işitsel ve sıralı/bütünsel olmak üzere envanterde bulunmaktadır. Veri toplama aracında 44 madde yer almaktadır. Her boyut için 11 madde bulunmaktadır. Her bir madde a ve b olmak üzere iki seçime sahiptir. Veri toplama aracındaki "a" seçenekleri, sahip olduğu boyutun yaparak, hissederek, görsel veya sıralı kısmını, " $b$ ” seçenekleri ise ilgili boyutun düşünerek, sezgisel, işitsel ve bütünsel kısımlarını ifade etmektedir. "a" ve b seçeneklerinin seçilme durumuna göre bireyin sahip olduğu öğrenme stilinin derecesi zayıf, orta ve güçlü olmak üzere değerlendirilmektedir (Samancı \& Keskin, 2007).

Veri toplama aracını Türkçe'ye uyarlayan Samancı ve Keskin (2007) yapmış oldukları araştırmada aracın genel Cronbach alfa değerini 0,64 olarak tespit etmiştir. Öğrenme stilinin boyutlarını ise ayrı ayrı, yap/düş 0,43, his/sez 0,54, gör/işit 0,59 ve sıra/büt 0,32 olarak bulmuştur. $\mathrm{Bu}$ araştırmada genel Cronbach alfa değeri 0,57 olarak tespit edilmişken; öğrenme stillerinin boyutları ise yap/düş 0,39 , his/sez 0,50 , gör/işit 0,55 ve sıra/büt 0,29 olarak belirlenmiştir. Görüldüğü gibi öğrenme stili envanterinin iç tutarlılık değerleri düşük çıkmıştır. Eğer veri analizi zıt kutuplu ise bu çalışmalarda iç tutarlılık değerleri düşük çıkabileceği belirtilmiştir (Fer, 2003; aktaran Şeker Sır, Karataş \& Çeliköz, 2015).

\section{Verilerin Analizi}

Verilerin analizinde SPSS paket programı kullanılmıştır. İki değişkenli verilerin karşılaştırılmasında t-testi, ikiden fazla değişkenli verilerin analizinde tek yönlü varyans 
analizi (ANOVA) kullanılmıştır. Tablo 2'de Felder ve Soloman Öğrenme Stilleri Envanteri'ndeki alt boyutlara ait maddeler ve envanterin puanlandırma sunulmuştur (Felder \& Soloman, 1994).

Tablo 2. Öğretim stilleri boyutları ve puanlandırması

\begin{tabular}{|c|c|c|c|c|c|c|c|c|c|c|c|}
\hline \multicolumn{3}{|c|}{ Yap/Düş } & \multicolumn{3}{|c|}{ His/Sez } & \multicolumn{3}{|c|}{ Gör/İşit } & \multicolumn{3}{|c|}{ Sıra/Büt } \\
\hline & a & $\mathrm{b}$ & & a & $\mathrm{b}$ & & a & $\mathrm{b}$ & & $\mathrm{a}$ & $\mathrm{b}$ \\
\hline 1 & & 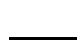 & 2 & 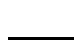 & $\longrightarrow$ & 3 & & $\longrightarrow$ & 4 & & 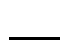 \\
\hline 5 & & 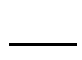 & 6 & & 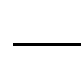 & 7 & & 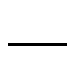 & 8 & & 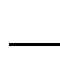 \\
\hline 9 & & 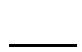 & 10 & - & 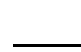 & 11 & & 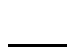 & 12 & & 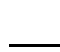 \\
\hline 13. & 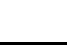 & 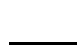 & 14 & 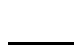 & 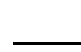 & 15 & & 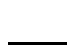 & 16 & 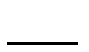 & 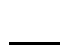 \\
\hline 17. & & 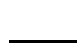 & 18 & & 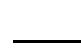 & 19 & & & 20 & & _ \\
\hline 21 & 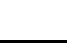 & 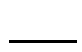 & 22 & & 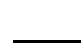 & 23 & & & 24 & & 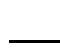 \\
\hline 25 & 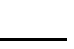 & - & 26 & & 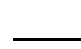 & 27 & & - & 28 & & 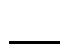 \\
\hline 29 & & - & 30 & & 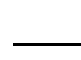 & 31 & & - & 32 & & 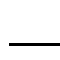 \\
\hline 33. & & - & 34 & - & 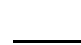 & 35 & & & 36 & & \\
\hline 37 & & - & 38 & . & 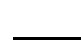 & 39 & & - & 40 & & $\ldots$ \\
\hline 41 & - & - & 42 & 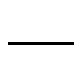 & 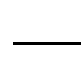 & 43 & 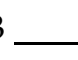 & - & 44 & 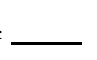 & 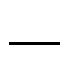 \\
\hline & & & opla & $\operatorname{am~}(s$ & ütunl & rin $h$ & her $b$ & topl & m1): & & \\
\hline & & /Düş & & His/ & & & Gör/1 & & & Sira/B & \\
\hline & a & $\mathrm{b}$ & & $\mathrm{a}$ & $\mathrm{b}$ & & a & $\mathrm{b}$ & & $\mathrm{a}$ & $\mathrm{b}$ \\
\hline
\end{tabular}

- Örneğin; 7 adet $\mathrm{a}, 4$ adet $\mathrm{b}$ seçersen, $7-4=3$ olarak değerlendirilmeye alınır. Ĕğer 7 adet $\mathrm{b}, 4$ adet $\mathrm{a}$ seçilirse $4-7=-3$ olarak değerlendirilmeye alınır.

Yap Düş

\begin{tabular}{lllllllllll}
\hline $11 a$ & $9 a$ & $7 a$ & $5 a$ & $3 a$ & $1 a$ & $-1 b$ & $-3 b$ & $-5 b$ & $-7 b-9 b$ & $-11 b$
\end{tabular}

His

$\begin{array}{lllllllllll}\text { Sez } & \\ 11 a & 9 a & 7 a & 5 a & 3 a & 1 a & -1 b & -3 b & -5 b & -7 b-9 b & -11 b\end{array}$

Gör

\begin{tabular}{lllllllllll} 
İşit & \\
\hline $11 a$ & $9 a$ & $7 a$ & $5 a$ & $3 a$ & $1 a$ & $-1 b$ & $-3 b$ & $-5 b$ & $-7 b-9 b$ & $-11 b$
\end{tabular}

Sira

\begin{tabular}{lllllllllll} 
Büt & \\
\hline $11 a$ & $9 a$ & $7 a$ & $5 a$ & $3 a$ & $1 a$ & $-1 b$ & $-3 b$ & $-5 b$ & $-7 b-9 b$ & $-11 b$
\end{tabular}

Eğer öğretmen adayının puan değeri 1-3 arası olursa öğretmen adayı, zayıf düzey öğrenme stili, 5-7 arası olursa orta düzey, 9-11 arası olursa yüksek düzey öğrenme stiline sahip olur (Samancı \& Keskin, 2007). 


\section{Bulgular}

Bu bölümde Fen Bilimleri öğretmen adaylarının belirli değişkenlere göre öğrenme stilleri envanterine ait bulgular yer almaktadır. Öğretmen adaylarının öğrenme stili envanterine vermiş olduğu yanıtlara göre oluşan her boyut için ayrı ayrı ortalama puan, maksimum ve minimum değer ve öğrenme stili düzeyi Tablo 3 'te sunulmuştur.

Tablo 3. Öğretmen adaylarının öğrenme stili düzeyleri

\begin{tabular}{cccccc}
\hline $\begin{array}{c}\text { Öğrenme Stili } \\
\text { Boyutları }\end{array}$ & $\begin{array}{c}\text { Kişi } \\
\text { Sayısı }\end{array}$ & $\begin{array}{c}\text { Ortalama } \\
\text { Puan }\end{array}$ & Maksimum & Minimum & $\begin{array}{c}\text { Öğrenme Stili } \\
\text { Düzeyi }\end{array}$ \\
\hline Yap/Düşs & 322 & 1,0590 & 9,00 & $-9,00$ & Zayıf \\
\hline His/Sez & 322 & 2,4161 & 11,00 & $-11,00$ & Zayıf \\
\hline Gör/İsit & 322 & 5,0404 & 11,00 & $-7,00$ & Orta \\
\hline Sıra/Büt & 322 & 1,6677 & 11,00 & $-11,00$ & Zayıf \\
\hline
\end{tabular}

Tablo 3 incelendiğinde öğretmen adaylarının öğrenme stilleri puan ortalamaları pozitif olarak tespit edilmiştir. Sahip oldukları baskın öğrenme stillerine göre öğretmen adayları yaparak, hissederek, görsel ve sıralı öğrenme stiline sahiplerdir. Öğretmen adaylarının yaparak, hissederek ve sıralı öğrenme stili düzeyleri zayıf düzey, görsel öğrenme stili düzeyleri ise orta düzey olarak bulunmuştur.

Öğretmen adaylarına uygulanan öğrenme stili envanterinden elde edilen bulgular bağımsız değişkenlere ait betimsel istatistik değerleri Tablo 4 'te sunulmuştur.

Tablo 4. Bağımsız değişkenlere ait betimsel istatistik değerleri

\begin{tabular}{|c|c|c|c|}
\hline Bağımsız Değişken & Gruplar & Frekans (F) & Yüzde (\%) \\
\hline \multirow{2}{*}{ Cinsiyet } & Kadın & 245 & 76,1 \\
\hline & Erkek & 77 & 23,9 \\
\hline \multirow{4}{*}{ Sınıf Düzeyi } & 1. Sinif & 87 & 27,0 \\
\hline & 2. Sinif & 81 & 25,2 \\
\hline & 3. Sinif & 77 & 23,9 \\
\hline & 4. Sinif & 77 & 23,9 \\
\hline \multirow{3}{*}{ Mezun Olduğu Lise } & Anadolu Lisesi & 150 & 46,6 \\
\hline & Düz Lise & 109 & 33,9 \\
\hline & Meslek Lisesi & 63 & 19,6 \\
\hline \multirow{2}{*}{ Okul Öncesi Eğitim Durumu } & Hayır & 231 & 71,7 \\
\hline & Evet & 91 & 28,3 \\
\hline \multirow{2}{*}{ Barınma Yeri } & Ev & 115 & 35,7 \\
\hline & Yurt & 207 & 64,3 \\
\hline \multirow{4}{*}{ Anne Eğitim Durumu } & İlkokul & 195 & 60,6 \\
\hline & Ortaokul & 66 & 20,5 \\
\hline & Lise & 52 & 16,1 \\
\hline & Üniversite & 9 & 2,8 \\
\hline \multirow{3}{*}{ Baba Eğitim Durumu } & İlkokul & 117 & 36,3 \\
\hline & Ortaokul & 79 & 24,5 \\
\hline & Lise & 83 & 25,8 \\
\hline
\end{tabular}




\begin{tabular}{llcc}
\hline & Üniversite & 43 & 13,4 \\
\hline \multirow{3}{*}{ Anne Çalışma Durumu } & Çalışmiyor & 250 & 77,6 \\
\cline { 2 - 4 } & Çalışıyor & 60 & 18,6 \\
\cline { 2 - 4 } & Emekli & 12 & 3,7 \\
\hline \multirow{3}{*}{ Baba Çalışma Durumu } & Çalışmiyor & 19 & 5,9 \\
\cline { 2 - 4 } & Çalışıyor & 237 & 73,6 \\
\cline { 2 - 4 } & Emekli & 66 & 20,5 \\
\hline
\end{tabular}

Öğretmen adaylarının cinsiyet değişkenine göre öğrenme stili alt boyutlarının farklılaşıp farklılaşmadığının tespiti için t-testi analizi yapılmıştır. T-testi analizine geçmeden önce kadın ve erkek gruplarının varyanslarının homojenliği Levene testi ile test edilmiştir (Büyüköztürk, 2011). Öğrenme stilleri alt boyutların Levene testi değerleri .05 ’ten büyük değer aldığı için varyanslar homojendir. Dolayısıyla t testi için ön koşul sağlanmıştır. Buna göre $\mathrm{t}$ testi analiz sonuçları Tablo 5'te yer almaktadır.

Tablo 5. Öğrenme stili alt boyutları puanlarının cinsiyete göre t-testi sonuçları

\begin{tabular}{|c|c|c|c|c|c|c|c|}
\hline $\begin{array}{c}\text { Öğrenme Stili Alt } \\
\text { Boyutları }\end{array}$ & Gruplar & $\mathrm{N}$ & Ortalama & $\begin{array}{c}\text { Standart } \\
\text { Sapma }\end{array}$ & $\begin{array}{c}\text { Standart } \\
\text { Hata }\end{array}$ & $\mathrm{t}$ & $\begin{array}{l}\text { Anlamlilik } \\
(p)\end{array}$ \\
\hline \multirow{2}{*}{ Yap/Düş } & Kadın & 245 & 1,0980 & 3,60421 & ,23026 & \multirow{2}{*}{0,332} & \multirow{2}{*}{,740 } \\
\hline & Erkek & 77 & ,9351 & 4,20632 & ,47935 & & \\
\hline \multirow{2}{*}{ His/Sez } & Kadın & 245 & 2,8449 & 3,78636 & 24190 & \multirow{2}{*}{3,491} & \multirow{2}{*}{, $001^{*}$} \\
\hline & Erkek & 77 & 1,0519 & 4,36462 & ,49739 & & \\
\hline \multirow{2}{*}{ Gör/İşit } & Kadın & 245 & 5,4816 & 3,88733 & 24835 & \multirow{2}{*}{3,542} & \multirow{2}{*}{, $000^{*}$} \\
\hline & Erkek & 77 & 3,6364 & 4,29170 & ,48908 & & \\
\hline \multirow{2}{*}{ Sıra/Büt } & Kadın & 245 & 1,8816 & 3,65610 & 23358 & \multirow{2}{*}{1,847} & \multirow{2}{*}{,066 } \\
\hline & Erkek & 77 & ,9870 & 3,86786 & ,44078 & & \\
\hline
\end{tabular}
${ }^{{ }^{*} p<.05}$

Tablo 5 incelendiğinde yapılan t-testi sonuçlarına göre, öğretmen adaylarının cinsiyetlerine ilişkin öğrenme stilleri alt boyutlarından “hissederek/sezgisel” ( $t=3.491 ; p<.05)$ ve "görsel/işitsel" ( $\mathrm{t}=3.542 ; \mathrm{p}<.05)$ boyut puanları arasında anlamlı bir farklılık tespit edilmiştir. Kadın öğretmen adaylarının erkek öğretmen adaylarına göre hissederek ve görsel öğrenme stillerinin anlamlı derecede farklılık gösterdiği tespit edilmiştir. Ancak, yaparak/düşünerek ve sıralı/bütünsel alt boyut puanları arasında cinsiyet değişkenine göre anlamlı farklılık görülmemiştir (sırasıyla $\mathrm{t}=0.332$ ve $\mathrm{t}=1.847$; $\mathrm{p}>.05$ ).

Öğretmen adaylarının sınıf düzeylerine göre öğrenme stilleri betimsel istatistikleri Tablo 6' da sunulmuştur. 
Tablo 6. Öğrenme stili alt boyut puanlarının sınıf düzeylerine ilişkin betimsel istatistikleri

\begin{tabular}{|c|c|c|c|c|c|}
\hline Öğrenme Stili Boyutları & Sınıf Düzeyi & $\mathbf{N}$ & Ortalama & Standart Sapma & $\begin{array}{c}\text { Standart } \\
\text { Hata } \\
\end{array}$ \\
\hline \multirow{5}{*}{ Yap/Düş } & 1. Sinif & 87 & 8506 & 3,81103 & 40858 \\
\hline & 2. Sinif & 81 & ,9383 & 3,84170 & 42686 \\
\hline & 3. Sinif & 77 & 1,0000 & 4,16754 & ,47494 \\
\hline & 4. Sinif & 77 & 1,4805 & 3,13558 & ,35733 \\
\hline & Toplam & 322 & 1,0590 & 3,75075 & 20902 \\
\hline \multirow{5}{*}{ His/Sez } & 1. Sinif & 87 & 3,1264 & 3,86939 & 41484 \\
\hline & 2. Sinif & 81 & 1,6420 & 4,45620 & ,49513 \\
\hline & 3. Sinif & 77 & 2,7403 & 3,61067 & , 41147 \\
\hline & 4. Sinif & 77 & 2,1039 & 3,90541 & ,44506 \\
\hline & Toplam & 322 & 2,4161 & 3,99931 & 22287 \\
\hline \multirow{5}{*}{ Gör/İşit } & 1. Sinif & 87 & 4,1149 & 3,93383 & 42175 \\
\hline & 2. Sinif & 81 & 3,9383 & 4,40269 & 48919 \\
\hline & 3. Sinif & 77 & 6,2727 & 3,72981 & ,42505 \\
\hline & 4. Sinif & 77 & 6,0130 & 3,60005 & ,41026 \\
\hline & Toplam & 322 & 5,0404 & 4,05817 & ,22615 \\
\hline \multirow{5}{*}{ Sira/Büt } & 1. Sinif & 87 & 2,3448 & 3,60822 & ,38684 \\
\hline & 2. Sinif & 81 & 1,6420 & 4,19019 & ,46558 \\
\hline & 3. Sinif & 77 & 1,0909 & 3,29745 & ,37578 \\
\hline & 4. Sinif & 77 & 1,5065 & 3,67647 & ,41897 \\
\hline & Toplam & 322 & 1,6677 & 3,72139 & ,20738 \\
\hline
\end{tabular}

Öğretmen adaylarının sınıf düzeylerine göre hangi öğrenme stilinin baskın olduğu ve öğrenme stili alt boyutları arasında sınıf düzeylerine göre anlamlı farklılı̆̆ın olup olmadığının tespiti için tek yönlü varyans analizi yöntemi (ANOVA) uygulanmıştır. ANOVA uygulanmadan önce gruplarının varyans eşitliği belirlenmelidir. Grup varyanslarının eşitliği için Levene testine başvurulmuştur. Levene testi sonucu anlamlılık değeri .05'ten büyük çıkması grupların varyanslarının eşit olduğunu gösterir. Grup varyansları eşit bulunduğu için ANOVA'ya geçilir (Durmuş, Yurtkoru \& Çinko, 2011; Büyüköztürk, 2011).

Tablo 7. Öğrenme stili alt boyutu puanlarının grup varyanslarının eşitliği testi

\begin{tabular}{ccccc}
\hline $\begin{array}{c}\text { Öğrenme Stilleri } \\
\text { Boyutları }\end{array}$ & $\begin{array}{c}\text { Levene } \\
\text { İstatistik }\end{array}$ & $\begin{array}{c}\text { Serbestlik } \\
\text { Derecesi 1 }\end{array}$ & $\begin{array}{c}\text { Serbestlik } \\
\text { Derecesi 2 }\end{array}$ & $\begin{array}{c}\text { Anlamlılık } \\
\text { (p) }\end{array}$ \\
\hline Yap/Düş & 2,550 & 3 & 318 &, 056 \\
\hline His/Sez & 1,640 & 3 & 318 &, 180 \\
\hline Gör/İşit & 1,802 & 3 & 318 &, 147 \\
\hline Sıra/Büt & 2,260 & 3 & 318 &, 081 \\
\hline
\end{tabular}

Tablo 7'den görüleceği gibi Levene testi sonucunda öğrenme stilleri alt boyutlarının tamamında grup varyansları eşit olarak tespit edilmiştir ( $p>.05)$. 
Öğretmen adaylarının öğrenme stilleri alt boyutlarına ilişkin sınıf düzeylerine göre ANOVA testi sonuçları Tablo 8'de sunulmuştur.

Tablo 8. Öğrenme stilleri alt boyutlarının öğretmen adaylarının sınıf düzeylerine göre karşılaştırılmasına ilişkin tek yönlü varyans analizi (ANOVA) sonuçları

\begin{tabular}{|c|c|c|c|c|c|c|}
\hline $\begin{array}{c}\text { Öğrenme Stilleri } \\
\text { Alt Boyutları }\end{array}$ & $\begin{array}{c}\text { Varyansın } \\
\text { Kaynağı }\end{array}$ & $\begin{array}{c}\text { Kareler } \\
\text { Toplamı } \\
\end{array}$ & $\begin{array}{c}\text { Serbestlik } \\
\text { Derecesi }\end{array}$ & $\begin{array}{c}\text { Kareler } \\
\text { Ortalaması }\end{array}$ & $\mathbf{F}$ & $\mathbf{p}$ \\
\hline \multirow{3}{*}{ Yap/Düş } & Gruplar arası & 18,909 & 3 & 6,303 & \multirow[t]{3}{*}{,446 } & \multirow[t]{3}{*}{ 720 } \\
\hline & Gruplar içi & 4496,970 & 318 & 14,141 & & \\
\hline & Toplam & 4515,879 & 321 & & & \\
\hline \multirow{3}{*}{$\mathrm{His} / \mathrm{Sez}$} & Gruplar arası & 108,036 & 3 & 36,012 & \multirow[t]{3}{*}{2,278} & \multirow[t]{3}{*}{,079 } \\
\hline & Gruplar içi & 5026,201 & 318 & 15,806 & & \\
\hline & Toplam & 5134,236 & 321 & & & \\
\hline \multirow{3}{*}{ Gör/İşit } & Gruplar arası & 362,673 & 3 & 120,891 & \multirow[t]{3}{*}{7,808} & \multirow[t]{3}{*}{, $000^{\circ}$} \\
\hline & Gruplar içi & 4923,802 & 318 & 15,484 & & \\
\hline & Toplam & 5286,475 & 321 & & & \\
\hline \multirow{3}{*}{ Sira/Büt } & Gruplar arası & 67,561 & 3 & 22,520 & \multirow[t]{3}{*}{1,636} & \multirow[t]{3}{*}{,181 } \\
\hline & Gruplar içi & 4377,883 & 318 & 13,767 & & \\
\hline & Toplam & 4445,444 & 321 & & & \\
\hline
\end{tabular}

Öğretmen adaylarının "sınıf düzeylerine" göre karşılaştırılmasına ilişkin öğrenme stilleri alt boyutlarından "görsel/işitsel" alt boyutu bakımından anlamlı farklılık tespit edilmiştir ( $\mathrm{F}=7.808 ; \mathrm{p}<.001)$. Bu farklılı̆̆ın hangi gruplar arasında olduğunun belirlenmesi için Scheffe testine başvurulmuştur. ANOVA analizi neticesinde grup varyanslarının eşit olarak belirlendiği çalışmalarda genellikle ikili karşılaştırma testlerinden olan Scheffe testi de kullanılmaktadır (Durmuş ve ark., 2011).

Öğretmen adaylarının görsel/işitsel öğrenme stili alt boyutuna ilişkin sınıf düzeylerine göre Scheffe ikili karşılaştırma testi sonuçları Tablo 9'da yer almaktadır.

Tablo 9. Görsel/İ̧sitsel öğrenme stili alt boyutuna ilişkin öğretmen adaylarının sınıf düzeylerine göre Scheffe ikili karşılaştırma testi sonuçları

\begin{tabular}{|c|c|c|c|c|c|}
\hline & Gruplar & Gruplar & Farkların Ortalaması & Standart Hata & Anlamlılık (p) \\
\hline \multirow{12}{*}{ Gör/işit } & \multirow[t]{3}{*}{ 1. Sinif } & \multirow{3}{*}{$\begin{array}{l}\text { 2. Sinif } \\
\text { 3. Sinıf } \\
\text { 4. Sinif }\end{array}$} & ,17667 & ,60756 & ,994 \\
\hline & & & $-2,15778$ & 61568 &, $007^{*}$ \\
\hline & & & $-1,89804$ & 61568 &, $025^{*}$ \\
\hline & \multirow[t]{3}{*}{ 2. Sinif } & 1. Sinif &,- 17667 & ,60756 & ,994 \\
\hline & & 3. Sinif & $-2,33446$ & ,62629 & ,003* \\
\hline & & 4. Sinif & $-2,07472$ & ,62629 &, $013^{*}$ \\
\hline & \multirow[t]{3}{*}{ 3. Sinif } & 1. Sinif & 2,15778 & ,61568 & ,007* \\
\hline & & 2. Sinif & 2,33446 & ,62629 & ,003* \\
\hline & & 4. Sinif & 25974 & 63417 & ,983 \\
\hline & \multirow[t]{3}{*}{ 4. Sinif } & 1. Sinif & 1,89804 & 61568 &, $025^{*}$ \\
\hline & & 2. Sinif & 2,07472 & 62629 & ,013* \\
\hline & & 3. Sinif &,- 25974 & 63417 & ,983 \\
\hline
\end{tabular}

${ }^{*} p<.05$ 
Tablo 9 incelendiğinde, ikili karşılaştırma testine göre, 1. sınıf öğretmen adayları ile 3. ve 4. sınıf öğretmen adayları arasında üst sınıflar lehine anlamlı farklılık vardır. Diğger bir bulgu, 2. sinıflar ile 3. ve 4. sinıflar arasında yine üst sinıflar lehine anlamlı farklılık bulunmuştur. Ancak 1. sınıf öğretmen adayları ile 2. sınıf; 3. sınıf öğretmen adayları ile 4. sınıf öğretmen adayları arasında anlamlı farklılık tespit edilmemiştir.

Öğretmen adaylarının mezun oldukları lise türüne göre öğrenme stilleri betimsel istatistikleri Tablo 10' da sunulmuştur.

Tablo 10. Öğrenme stili alt boyut puanlarının lise mezuniyet türüne ilişkin betimsel istatistikleri

\begin{tabular}{cccccc}
\hline Öğrenme Stili Boyutları & Sinıf Düzeyi & $\mathbf{N}$ & Ortalama & Standart Sapma & $\begin{array}{c}\text { Standart } \\
\text { Hata }\end{array}$ \\
\hline \multirow{3}{*}{ Yap/Düş } & Anadolu Lisesi & 150 & 1,0267 & 3,93734 &, 32148 \\
\cline { 2 - 6 } & Düz Lise & 109 & 1,1193 & 3,26521 &, 31275 \\
\cline { 2 - 6 } & Meslek Lisesi & 63 & 1,0317 & 4,12298 &, 51945 \\
\cline { 2 - 6 } & Toplam & 322 & 1,0590 & 3,75075 &, 20902 \\
\hline \multirow{3}{*}{ His/Sez } & Anadolu Lisesi & 150 & 2,7067 & 4,04264 &, 33008 \\
\cline { 2 - 6 } & Düz Lise & 109 & 2,1560 & 4,22553 &, 40473 \\
\cline { 2 - 6 } & Meslek Lisesi & 63 & 2,1746 & 3,47126 &, 43734 \\
\cline { 2 - 6 } & Toplam & 322 & 2,4161 & 3,99931 &, 22287 \\
\hline \multirow{5}{*}{ Gör/İşit } & Anadolu Lisesi & 150 & 5,3733 & 3,79429 &, 30980 \\
\cline { 2 - 6 } & Düz Lise & 109 & 5,0734 & 4,44036 &, 42531 \\
\cline { 2 - 6 } & Meslek Lisesi & 63 & 4,1905 & 3,91382 &, 49309 \\
\cline { 2 - 6 } & Toplam & 322 & 5,0404 & 4,05817 &, 22615 \\
\hline \multirow{3}{*}{ Sira/Büt } & Anadolu Lisesi & 150 & 1,5800 & 3,74393 &, 34659 \\
\cline { 2 - 6 } & Düz Lise & 109 & 1,9817 & 3,59779 &, 20736 \\
\cline { 2 - 6 } & Meslek Lisesi & 63 & 1,3333 & 3,89375 &, 49057 \\
\cline { 2 - 6 } & Toplam & 322 & 1,6677 & 3,72139 &, \\
& & & & \\
\hline
\end{tabular}

Öğretmen adaylarının lise mezuniyet türüne ilişkin hangi öğrenme stilinin baskın olduğu ve öğrenme stili alt boyutları arasında lise mezuniyet türüne göre anlamlı farklılığın olup olmadığının tespiti için tek yönlü varyans analizi yöntemi (ANOVA) uygulanmıştır. ANOVA uygulanmadan önce gruplarının varyans eşitliği için Levene testi yapılmıştır. Levene testi istatistik değerleri Tablo 11 'de yer almaktadır.

Tablo 11. Öğrenme stili alt boyutu puanlarının grup varyanslarının eşitliği testi

\begin{tabular}{ccccc}
\hline $\begin{array}{c}\text { Öğrenme Stilleri } \\
\text { Boyutları }\end{array}$ & $\begin{array}{c}\text { Levene } \\
\text { İstatistik }\end{array}$ & $\begin{array}{c}\text { Serbestlik } \\
\text { Derecesi 1 }\end{array}$ & $\begin{array}{c}\text { Serbestlik } \\
\text { Derecesi 2 }\end{array}$ & $\begin{array}{c}\text { Anlamlılık } \\
\text { (p) }\end{array}$ \\
\hline Yap/Düş & 2,547 & 2 & 319 &, 080 \\
\hline His/Sez & 1,129 & 2 & 319 &, 325 \\
\hline Gör/İşit &, 946 & 2 & 319 &, 390 \\
\hline Sıra/Büt &, 029 & 2 & 319 &, 972 \\
\hline
\end{tabular}


Tablo 11'den görüleceği gibi Levene testi sonucunda öğrenme stilleri alt boyutlarının tamamında grup varyansları eşit olarak tespit edilmiştir ( $\mathrm{p}>.05)$.

Öğretmen adaylarının öğrenme stilleri alt boyutlarına ilişkin mezun oldukları lise türüne göre ANOVA testi sonuçları Tablo 12' de sunulmuştur.

Tablo 12. Öğrenme stilleri alt boyutlarının öğretmen adaylarının mezun oldukları lise türüne göre karşılaştırılmasına ilişkin tek yönlü varyans analizi (ANOVA) sonuçları

\begin{tabular}{|c|c|c|c|c|c|c|}
\hline $\begin{array}{l}\text { Öğrenme Stilleri } \\
\text { Alt Boyutları }\end{array}$ & $\begin{array}{l}\text { Varyansın } \\
\text { Kaynağı }\end{array}$ & $\begin{array}{c}\text { Kareler } \\
\text { Toplamı }\end{array}$ & $\begin{array}{c}\text { Serbestlik } \\
\text { Derecesi }\end{array}$ & $\begin{array}{c}\text { Kareler } \\
\text { Ortalaması }\end{array}$ & F & $\mathbf{p}$ \\
\hline \multirow{3}{*}{ Yap/Düş } & Gruplar arası &, 599 & 2 & ,300 & ,021 & ,979 \\
\hline & Gruplar içi & 4515,279 & 319 & 14,154 & & \\
\hline & Toplam & 4515,879 & 321 & & & \\
\hline \multirow{3}{*}{ His/Sez } & Gruplar arası & 23,715 & 2 & 11,857 & 740 & 478 \\
\hline & Gruplar içi & 5110,521 & 319 & 16,020 & & \\
\hline & Toplam & 5134,236 & 321 & & & \\
\hline \multirow{3}{*}{ Gör/İşit } & Gruplar arası & 62,255 & 2 & 31,127 & 1,901 & 151 \\
\hline & Gruplar içi & 5224,220 & 319 & 16,377 & & \\
\hline & Toplam & 5286,475 & 321 & & & \\
\hline \multirow{3}{*}{ Sira/Büt } & Gruplar arası & 18,941 & 2 & 9,470 & 682 &, 506 \\
\hline & Gruplar içi & 4426,503 & 319 & 13,876 & & \\
\hline & Toplam & 4445,444 & 321 & & & \\
\hline
\end{tabular}

Öğretmen adaylarının "mezun oldukları lise türüne" göre karşılaştırılmasına ilişkin öğrenme stilleri alt boyutları bakımından aralarında anlamlı farklılık tespit edilmemiştir.

Öğretmen adaylarının Okul öncesi eğitim alma duruma göre öğrenme stili alt boyutlarının farklılaşıp farklılaşmadığının tespiti için $\mathrm{t}$ testi analizi yapılmıştır. $\mathrm{T}$ testi analizine geçmeden önce gruplarının varyanslarının homojenliği Levene testi ile test edilmiştir. Öğrenme stilleri alt boyutların Levene testi değerleri .05’ten büyük değer aldığ için varyanslar homojendir.

Öğretmen adaylarının öğrenme stilleri alt boyut puanlarının okul öncesi eğitim durumu değişkenine göre aralarında farklılık olup olmadığının tespiti için $t$ testi uygulanmıştır. Buna göre değerler Tablo 13'te yer almaktadır. 
Tablo 13. Öğrenme stili alt boyutları puanlarının okul öncesi eğitim durumuna göre t-testi sonuçları

\begin{tabular}{|c|c|c|c|c|c|c|c|}
\hline $\begin{array}{c}\text { Öğrenme Stili Alt } \\
\text { Boyutları }\end{array}$ & Gruplar & $\mathrm{N}$ & Ortalama & $\begin{array}{l}\text { Standart } \\
\text { Sapma }\end{array}$ & $\begin{array}{c}\text { Standart } \\
\text { Hata } \\
\end{array}$ & $\mathrm{t}$ & $\begin{array}{c}\text { Anlamlilık } \\
(\mathrm{p})\end{array}$ \\
\hline \multirow{2}{*}{ Yap/Düş } & Hayır & 231 & 9913 & 3,76943 & 24801 & \multirow{2}{*}{,- 515} & \multirow{2}{*}{,607 } \\
\hline & Evet & 91 & 1,2308 & 3,71805 & ,38976 & & \\
\hline \multirow{2}{*}{$\mathrm{His} / \mathrm{Sez}$} & Hayır & 231 & 2,2468 & 4,16138 & ,27380 & \multirow{2}{*}{$\begin{array}{c}- \\
1,212\end{array}$} & \multirow{2}{*}{,226 } \\
\hline & Evet & 91 & 2,8462 & 3,54000 & 37109 & & \\
\hline \multirow{2}{*}{ Gör/İşit } & Hayır & 231 & 5,2814 & 3,92578 & ,25830 & \multirow{2}{*}{1,703} & \multirow{2}{*}{,090 } \\
\hline & Evet & 91 & 4,4286 & 4,33882 & ,45483 & & \\
\hline \multirow{2}{*}{ Sıra/Büt } & Hayır & 231 & 1,5584 & 3,71540 & ,24446 & \multirow{2}{*}{,- 839} & \multirow{2}{*}{,402 } \\
\hline & Evet & 91 & 1,9451 & 3,74273 & ,39235 & & \\
\hline
\end{tabular}

Tablo 13 incelendiğinde yapılan $\mathrm{t}$ testi sonuçlarına göre, öğretmen adaylarının okul öncesi eğitim alma duruma ilişkin öğrenme stilleri alt boyut puanları arasında anlamlı farklılık tespit edilmemiştir ( $\mathrm{p}>$.05). Dolayısıyla okul öncesi eğitim alan öğretmen adayları ile okul öncesi eğitim almayan öğretmen adayları arasında öğrenme stilleri bakımından farklılık görülmemiştir.

Öğretmen adaylarının barınma yeri değişkenine göre öğrenme stili alt boyutlarının farklılaşıp farklılaşmadığının tespiti için $t$ testi analizi yapılmıştır. T testi analizine geçmeden önce kadın ve erkek gruplarının varyanslarının homojenliği Levene testi ile test edilmiştir. Öğrenme stilleri alt boyutların Levene testi değerleri .05'ten büyük değer aldı̆̆1 için varyanslar homojendir.

Öğretmen adaylarının öğrenme stilleri alt boyut puanlarının barınma yeri değişkenine göre aralarında farklılık olup olmadığının tespiti için t testi uygulanmıştır. Buna göre değerler Tablo 14'te yer almaktadır.

Tablo 14. Öğrenme stili alt boyutları puanlarının barınma yerine göre t-testi sonuçları

\begin{tabular}{|c|c|c|c|c|c|c|c|}
\hline $\begin{array}{c}\text { Öğrenme Stili Alt } \\
\text { Boyutları }\end{array}$ & Gruplar & $\mathrm{N}$ & Ortalama & $\begin{array}{c}\text { Standart } \\
\text { Sapma }\end{array}$ & $\begin{array}{c}\text { Standart } \\
\text { Hata }\end{array}$ & $\mathrm{t}$ & $\begin{array}{c}\text { Anlamlilık } \\
\text { (p) }\end{array}$ \\
\hline \multirow[b]{2}{*}{ Yap/Düş } & $\mathrm{Ev}$ & 115 & 1,2087 & 3,76152 & ,35076 & \multirow{2}{*}{, 533} & \multirow[b]{2}{*}{,594 } \\
\hline & Yurt & 207 & ,9758 & 3,75130 & ,26073 & & \\
\hline \multirow{2}{*}{ His/Sez } & $\mathrm{Ev}$ & 115 & 2,3826 & 3,95940 & ,36922 & \multirow{2}{*}{,- 112} & \multirow{2}{*}{,911 } \\
\hline & Yurt & 207 & 2,4348 & 4,03075 & ,28016 & & \\
\hline \multirow{2}{*}{ Gör/İşit } & $\mathrm{Ev}$ & 115 & 4,8261 & 4,19536 & ,39122 & \multirow{2}{*}{,- 706} & \multirow{2}{*}{,481 } \\
\hline & Yurt & 207 & 5,1594 & 3,98525 & 27699 & & \\
\hline \multirow{2}{*}{ Sıra/Büt } & $\mathrm{Ev}$ & 115 & 1,2870 & 3,60984 & ,33662 & \multirow{2}{*}{$\begin{array}{c}- \\
1,370\end{array}$} & \multirow{2}{*}{,172 } \\
\hline & Yurt & 207 & 1,8792 & 3,77394 & 26231 & & \\
\hline
\end{tabular}


Tablo 14 incelendiğinde yapılan $\mathrm{t}$ testi sonuçlarına göre, öğretmen adaylarının barınma yerlerine ilişkin öğrenme stilleri alt boyut puanları arasında anlamlı farklılık tespit edilmemiştir ( $p>$.05). Dolayısıyla evde kalan öğretmen adayları ile yurtta kalan öğretmen adayları arasında öğrenme stilleri bakımından farklılık görülmemiştir.

Öğretmen adaylarının anne eğitim durumuna göre öğrenme stilleri betimsel istatistikleri Tablo $15^{\prime}$ te sunulmuştur.

Tablo 15. Öğrenme stili alt boyut puanlarının anne eğitim durumuna ilişkin betimsel istatistikleri

\begin{tabular}{|c|c|c|c|c|c|}
\hline Öğrenme Stili Boyutları & Sınıf Düzeyi & $\mathbf{N}$ & Ortalama & Standart Sapma & $\begin{array}{c}\text { Standart } \\
\text { Hata }\end{array}$ \\
\hline \multirow{5}{*}{ Yap/Düş } & İlkokul & 195 & ,9744 & 3,74914 & ,26848 \\
\hline & Ortaokul & 66 & 1,0000 & 4,14729 & ,51050 \\
\hline & Lise & 52 & 1,6538 & 3,25928 & 45198 \\
\hline & Üniversite & 9 &,- 1111 & 3,48010 & 1,16003 \\
\hline & Toplam & 322 & 1,0590 & 3,75075 & 20902 \\
\hline \multirow{5}{*}{ His/Sez } & İlkokul & 195 & 2,4513 & 4,05394 & ,29031 \\
\hline & Ortaokul & 66 & 2,4697 & 3,81987 & ,47019 \\
\hline & Lise & 52 & 2,3077 & 4,30476 &, 59696 \\
\hline & Üniversite & 9 & 1,8889 & 2,47207 & 82402 \\
\hline & Toplam & 322 & 2,4161 & 3,99931 & ,22287 \\
\hline \multirow{5}{*}{ Gör/İşit } & İlkokul & 195 & 5,0308 & 4,23036 & ,30294 \\
\hline & Ortaokul & 66 & 5,1364 & 3,67062 & ,45182 \\
\hline & Lise & 52 & 4,9808 & 4,01219 & ,55639 \\
\hline & Üniversite & 9 & 4,8889 & 3,82245 & 1,27415 \\
\hline & Toplam & 322 & 5,0404 & 4,05817 & ,22615 \\
\hline \multirow{5}{*}{ Sıra/Büt } & İlkokul & 195 & 1,8103 & 3,74027 & ,26785 \\
\hline & Ortaokul & 66 & 1,4242 & 3,52163 & ,43348 \\
\hline & Lise & 52 & 1,4038 & 3,94203 & ,54666 \\
\hline & Üniversite & 9 & 1,8889 & 3,88730 & 1,29577 \\
\hline & Toplam & 322 & 1,6677 & 3,72139 & ,20738 \\
\hline
\end{tabular}

Öğretmen adaylarının anne eğitim durumuna göre hangi öğrenme stilinin baskın olduğu ve öğrenme stili alt boyutları arasında anne eğitim durumuna göre anlamlı farklılığın olup olmadığının tespiti için tek yönlü varyans analizi yöntemi (ANOVA) uygulanmıştır. ANOVA uygulanmadan önce gruplarının varyans eşitliği için Levene testi yapılmıştır. Levene testi istatistik değerleri Tablo 16 ' da yer almaktadır.

Tablo 16. Öğrenme stili alt boyutu puanlarının grup varyanslarının eşitliği testi

\begin{tabular}{ccccc}
\hline $\begin{array}{c}\text { Öğrenme Stilleri } \\
\text { Boyutları }\end{array}$ & $\begin{array}{c}\text { Levene } \\
\text { İstatistik }\end{array}$ & $\begin{array}{c}\text { Serbestlik } \\
\text { Derecesi 1 }\end{array}$ & $\begin{array}{c}\text { Serbestlik } \\
\text { Derecesi 2 }\end{array}$ & $\begin{array}{c}\text { Anlamlılık } \\
\text { (p) }\end{array}$ \\
\hline Yap/Düş & 1,113 & 3 & 318 &, 344 \\
\hline His/Sez & 1,312 & 3 & 318 &, 271 \\
\hline Gör/İşit &, 703 & 3 & 318 &, 551 \\
\hline Sıra/Büt &, 344 & 3 & 318 &, 794 \\
\hline
\end{tabular}

Tablo 16'dan görüleceği gibi Levene testi sonucunda öğrenme stilleri alt boyutlarının tamamında grup varyansları eşit olarak tespit edilmiştir ( $p>.05)$. 
Öğretmen adaylarının öğrenme stilleri alt boyutlarına ilişkin anne eğitim durumuna göre ANOVA testi sonuçları Tablo 17' de sunulmuştur.

Tablo 17. Öğrenme stilleri alt boyutlarının öğretmen adaylarının sınıf düzeylerine göre karşılaştırılmasına ilişkin tek yönlü varyans analizi (ANOVA) sonuçları

\begin{tabular}{|c|c|c|c|c|c|c|}
\hline $\begin{array}{c}\text { Öğrenme Stilleri } \\
\text { Alt Boyutları }\end{array}$ & $\begin{array}{c}\text { Varyansın } \\
\text { Kaynağ1 }\end{array}$ & $\begin{array}{c}\text { Kareler } \\
\text { Toplamı } \\
\end{array}$ & $\begin{array}{c}\text { Serbestlik } \\
\text { Derecesi } \\
\end{array}$ & $\begin{array}{c}\text { Kareler } \\
\text { Ortalaması } \\
\end{array}$ & $\mathbf{F}$ & $\mathrm{p}$ \\
\hline \multirow{3}{*}{ Yap/Düş } & Gruplar arası & 32,349 & 3 & 10,783 & \multirow[t]{3}{*}{,765 } & \multirow[t]{3}{*}{,514 } \\
\hline & Gruplar içi & 4483,530 & 318 & 14,099 & & \\
\hline & Toplam & 4515,879 & 321 & & & \\
\hline \multirow{3}{*}{ His/Sez } & Gruplar arası & 3,544 & 3 & 1,181 & \multirow[t]{3}{*}{073} & \multirow[t]{3}{*}{,974 } \\
\hline & Gruplar içi & 5130,692 & 318 & 16,134 & & \\
\hline & Toplam & 5134,236 & 321 & & & \\
\hline \multirow{3}{*}{ Gör/İşit } & Gruplar arası & 1,017 & 3 & ,339 & \multirow[t]{3}{*}{,020 } & \multirow[t]{3}{*}{,996 } \\
\hline & Gruplar içi & 5285,458 & 318 & 16,621 & & \\
\hline & Toplam & 5286,475 & 321 & & & \\
\hline \multirow{3}{*}{ Sıra/Büt } & Gruplar arası & 11,935 & 3 & 3,978 & \multirow[t]{3}{*}{285} & \multirow[t]{3}{*}{,836 } \\
\hline & Gruplar içi & 4433,509 & 318 & 13,942 & & \\
\hline & Toplam & 4445,444 & 321 & & & \\
\hline
\end{tabular}

Öğretmen adaylarının “anne eğitim durumuna” göre karşılaştırılmasına ilişkin öğrenme stilleri alt boyutları bakımından aralarında anlamlı farklılık tespit edilmemiştir.

Öğretmen adaylarının baba eğitim durumuna göre öğrenme stilleri betimsel istatistikleri Tablo 18' de sunulmuştur.

Tablo 18. Öğrenme stili alt boyut puanlarının baba eğitim durumuna ilişkin betimsel istatistikleri

\begin{tabular}{|c|c|c|c|c|c|}
\hline Öğrenme Stili Boyutları & Sınıf Düzeyi & $\mathbf{N}$ & Ortalama & Standart Sapma & $\begin{array}{c}\text { Standart } \\
\text { Hata }\end{array}$ \\
\hline \multirow{5}{*}{ Yap/Düş } & İlkokul & 117 & 1,0598 & 3,64666 & ,33713 \\
\hline & Ortaokul & 79 & 6709 & 4,25387 & 47860 \\
\hline & Lise & 83 & 1,3253 & 3,55483 & ,39019 \\
\hline & Üniversite & 43 & 1,2558 & 3,47161 & ,52941 \\
\hline & Toplam & 322 & 1,0590 & 3,75075 & ,20902 \\
\hline \multirow{5}{*}{ His/Sez } & İlkokul & 117 & 2,0256 & 4,10311 & ,37933 \\
\hline & Ortaokul & 79 & 2,7595 & 4,30329 & ,48416 \\
\hline & Lise & 83 & 2,7108 & 3,60396 & ,39559 \\
\hline & Üniversite & 43 & 2,2791 & 3,89337 & ,59373 \\
\hline & Toplam & 322 & 2,4161 & 3,99931 & ,22287 \\
\hline \multirow{5}{*}{ Gör/İşit } & İlkokul & 117 & 4,6752 & 3,87483 & ,35823 \\
\hline & Ortaokul & 79 & 5,4051 & 4,05260 & ,45595 \\
\hline & Lise & 83 & 5,8675 & 3,58102 & ,39307 \\
\hline & Üniversite & 43 & 3,7674 & 5,02298 & ,76600 \\
\hline & Toplam & 322 & 5,0404 & 4,05817 & ,22615 \\
\hline \multirow{5}{*}{ Sira/Büt } & İlkokul & 117 & 1,8205 & 3,66393 & ,33873 \\
\hline & Ortaokul & 79 & 1,6835 & 3,70912 & ,41731 \\
\hline & Lise & 83 & 1,7711 & 3,56242 & ,39103 \\
\hline & Üniversite & 43 & 1,0233 & 4,23415 & ,64570 \\
\hline & Toplam & 322 & 1,6677 & 3,72139 & ,20738 \\
\hline
\end{tabular}


Öğretmen adaylarının baba eğitim durumuna göre hangi öğrenme stilinin baskın olduğu ve öğrenme stili alt boyutları arasında anne eğitim durumuna göre anlamlı farklılığın olup olmadığının tespiti için tek yönlü varyans analizi yöntemi (ANOVA) uygulanmıştır. ANOVA uygulanmadan önce gruplarının varyans eşitliği için Levene testi yapılmıştır. Levene testi istatistik değerleri Tablo 19 'da yer almaktadır.

Tablo 19. Öğrenme stili alt boyutu puanlarının grup varyanslarının eşitliği testi

\begin{tabular}{ccccc}
\hline $\begin{array}{c}\text { Öğrenme Stilleri } \\
\text { Boyutları }\end{array}$ & $\begin{array}{c}\text { Levene } \\
\text { İstatistik }\end{array}$ & $\begin{array}{c}\text { Serbestlik } \\
\text { Derecesi 1 }\end{array}$ & $\begin{array}{c}\text { Serbestlik } \\
\text { Derecesi 2 }\end{array}$ & $\begin{array}{c}\text { Anlamlılık } \\
\text { (p) }\end{array}$ \\
\hline Yap/Düş & 1,352 & 3 & 318 &, 257 \\
\hline His/Sez &, 725 & 3 & 318 &, 538 \\
\hline Gör/İş̧it & 3,226 & 3 & 318 &, $023^{*}$ \\
\hline Sıra/Büt &, 197 & 3 & 318 &, 898 \\
\hline
\end{tabular}

${ }^{*} p<.05$

Tablo 19'dan görüleceği gibi Levene testi sonucunda yaparak/düşünerek, hissederek/sezgisel ve sıralı/bütünsel öğrenme stilleri alt boyutlarında grup varyansları eşit olarak tespit edilmiştir ( $\mathrm{p}>$.05). Ancak, görsel/işitsel öğrenme stili alt boyutu anlamlılık değeri bakımından $(\mathrm{p}<.05)$ varyansı homojen değildir. Grup varyanslarının homojen olmadığı durumlarda Tamhane'nin T2 testinin yapılması daha uygundur (Durmuş ve ark., 2011). Grup varyanslarının homojen olduğu durumlarda ise Scheffe testinin uygulanması daha uygundur.

Öğretmen adaylarının öğrenme stilleri alt boyutlarına ilişkin baba eğitim durumuna göre ANOVA testi sonuçları Tablo 20`de sunulmuştur.

Tablo 20. Öğrenme stilleri alt boyutlarının öğretmen adaylarının baba eğitim durumuna göre karşılaştırılmasına ilişkin tek yönlü varyans analizi (ANOVA) sonuçları

\begin{tabular}{|c|c|c|c|c|c|c|}
\hline $\begin{array}{l}\text { Öğrenme Stilleri } \\
\text { Alt Boyutları }\end{array}$ & $\begin{array}{l}\text { Varyansın } \\
\text { Kaynağ1 }\end{array}$ & $\begin{array}{c}\text { Kareler } \\
\text { Toplamı }\end{array}$ & $\begin{array}{c}\text { Serbestlik } \\
\text { Derecesi }\end{array}$ & $\begin{array}{c}\text { Kareler } \\
\text { Ortalaması }\end{array}$ & $\mathbf{F}$ & $\mathrm{p}$ \\
\hline \multirow{3}{*}{ Yap/Düş } & Gruplar arası & 19,452 & 3 & 6,484 & \multirow[t]{3}{*}{,459 } & \multirow[t]{3}{*}{ 711 } \\
\hline & Gruplar içi & 4496,427 & 318 & 14,140 & & \\
\hline & Toplam & 4515,879 & 321 & & & \\
\hline \multirow{3}{*}{$\mathrm{His} / \mathrm{Sez}$} & Gruplar arası & 35,171 & 3 & 11,724 & \multirow[t]{3}{*}{,731 } & \multirow[t]{3}{*}{,534 } \\
\hline & Gruplar içi & 5099,065 & 318 & 16,035 & & \\
\hline & Toplam & 5134,236 & 321 & & & \\
\hline \multirow{3}{*}{ Gör/İşit } & Gruplar arası & 152,562 & 3 & 50,854 & \multirow[t]{3}{*}{3,150} & \multirow[t]{3}{*}{, 025 } \\
\hline & Gruplar içi & 5133,913 & 318 & 16,144 & & \\
\hline & Toplam & 5286,475 & 321 & & & \\
\hline \multirow{3}{*}{ Sıra/Büt } & Gruplar arası & 21,497 & 3 & 7,166 & \multirow[t]{3}{*}{,515 } & \multirow[t]{3}{*}{ 672 } \\
\hline & Gruplar içi & 4423,947 & 318 & 13,912 & & \\
\hline & Toplam & 4445,444 & 321 & & & \\
\hline
\end{tabular}


Öğretmen adaylarının "baba eğitim durumuna" göre karşılaştırılmasına ilişkin öğrenme stilleri alt boyutlarından "görsel/işitsel" alt boyutu bakımından anlamlı farklılık tespit edilmiştir. $\mathrm{Bu}$ farklılığın hangi gruplar arasında olduğunun belirlenmesi için Tamhane'nin T2 testine başvurulmuştur.

Öğretmen adaylarının görsel/işitsel öğrenme stili alt boyutuna ilişkin sınıf düzeylerine göre Tamhane'nin T2 ikili karşılaştırma testi sonuçları Tablo 21'de yer almaktadır.

Tablo 21. Görsel/İşitsel öğrenme stili alt boyutuna ilişkin öğretmen adaylarının baba eğitim durumuna göre Tamhane ikili karşılaştırma testi sonuçları

\begin{tabular}{|c|c|c|c|c|c|}
\hline & Gruplar & Gruplar & Farkların Ortalaması & Standart Hata & Anlamlılık (p) \\
\hline \multirow{12}{*}{ Gör/işit } & \multirow[t]{3}{*}{ İlkokul } & Ortaokul &,- 72985 & ,57985 & ,757 \\
\hline & & Lise & $-1,19226$ & ,53182 & 147 \\
\hline & & Üniversite & 90777 & ,84562 & 869 \\
\hline & \multirow[t]{3}{*}{ Ortaokul } & İlkokul & ,72985 & ,57985 & ,757 \\
\hline & & Lise &,- 46241 & 60199 & ,970 \\
\hline & & Üniversite & 1,63762 & 89143 & 354 \\
\hline & \multirow[t]{3}{*}{ Lise } & İlkokul & 1,19226 & ,53182 & 147 \\
\hline & & Ortaokul & ,46241 & 60199 & 970 \\
\hline & & Üniversite & 2,10003 & ,86096 & , 100 \\
\hline & \multirow[t]{3}{*}{ Üniversite } & İlkokul &,- 90777 & 84562 & 869 \\
\hline & & Ortaokul & $-1,63762$ & ,89143 & ,354 \\
\hline & & Lise & $-2,10003$ & 86096 & 100 \\
\hline
\end{tabular}

${ }^{*} p<.05$

Öğretmen adaylarının "baba eğitim durumuna” göre karşılaştırılmasına ilişkin öğrenme stilleri alt boyutları bakımından aralarında anlamlı farklılık tespit edilmemiştir. ANOVA istatistiğine göre görsel/işitsel öğrenme stili alt boyutuna göre gruplar arası anlamlı farklılık bulunmasına rağmen ( $\mathrm{p}>.05)$, Tamhane ikili karşılaştırma testine göre aralarında anlamlı farklılık tespit edilmemiştir. Veri setinin daha geçerli olması için Dunnet's C ve Games-Howel testlerine de bakılmıştır. Gruplar arası varyansın homojen olmaması neticesinde uygulanacak diğer post-hoc istatistikleri Games-Howell ve Dunnet's C'dir (Kayri, 2009). Bu analizler neticesinde de Tamhane testinde olduğu gibi ikili gruplar arasında anlamlı farklılık bulunmamıştır ( $\mathrm{p}>.05)$.

Öğretmen adaylarının anne çalışma durumuna göre öğrenme stilleri betimsel istatistikleri Tablo 22' de sunulmuştur. 
Tablo 22. Öğrenme stili alt boyut puanlarının anne çalışma durumuna ilişkin betimsel istatistikleri

\begin{tabular}{|c|c|c|c|c|c|}
\hline Öğrenme Stili Boyutları & Sınıf Düzeyi & $\mathbf{N}$ & Ortalama & Standart Sapma & $\begin{array}{c}\text { Standart } \\
\text { Hata }\end{array}$ \\
\hline \multirow{4}{*}{ Yap/Düş } & Çalışmiyor & 250 & ,9280 & 3,73989 & ,23653 \\
\hline & Çalışıyor & 60 & 1,5500 & 3,87703 & ,50052 \\
\hline & Emekli & 12 & 1,3333 & 3,39340 & ,97959 \\
\hline & Toplam & 322 & 1,0590 & 3,75075 & ,20902 \\
\hline \multirow{4}{*}{ His/Sez } & Çalışmıyor & 250 & 2,5680 & 4,13980 & ,26182 \\
\hline & Çalışıyor & 60 & 1,8833 & 3,28887 & 42459 \\
\hline & Emekli & 12 & 1,9167 & 4,29499 & 1,23986 \\
\hline & Toplam & 322 & 2,4161 & 3,99931 & 22287 \\
\hline \multirow{4}{*}{ Gör/İşit } & Çalışmiyor & 250 & 5,0000 & 4,07461 & ,25770 \\
\hline & Çalışıyor & 60 & 5,5500 & 3,92914 & ,50725 \\
\hline & Emekli & 12 & 3,3333 & 4,16333 & 1,20185 \\
\hline & Toplam & 322 & 5,0404 & 4,05817 & ,22615 \\
\hline \multirow{4}{*}{ Sira/Büt } & Çalışmiyor & 250 & 1,7080 & 3,68198 & ,23287 \\
\hline & Çalışıyor & 60 & 1,8333 & 3,89335 &, 50263 \\
\hline & Emekli & 12 & , 0000 & 3,56753 & 1,02986 \\
\hline & Toplam & 322 & 1,6677 & 3,72139 & 20738 \\
\hline
\end{tabular}

Öğretmen adaylarının anne çalışma durumuna ilişkin hangi öğrenme stilinin baskın olduğu ve öğrenme stili alt boyutları arasında anne çalışma durumuna göre anlamlı farklılığın olup olmadığının tespiti için tek yönlü varyans analizi yöntemi (ANOVA) uygulanmıştır. ANOVA uygulanmadan önce gruplarının varyans eşitliği için Levene testi yapılmıştır. Levene testi istatistik değerleri Tablo 23'te yer almaktadır.

Tablo 23. Öğrenme stili alt boyutu puanlarının grup varyanslarının eşitliği testi

\begin{tabular}{ccccc}
\hline $\begin{array}{c}\text { Öğrenme Stilleri } \\
\text { Boyutları }\end{array}$ & $\begin{array}{c}\text { Levene } \\
\text { İstatistik }\end{array}$ & $\begin{array}{c}\text { Serbestlik } \\
\text { Derecesi 1 }\end{array}$ & $\begin{array}{c}\text { Serbestlik } \\
\text { Derecesi 2 }\end{array}$ & $\begin{array}{c}\text { Anlamlılık } \\
\text { (p) }\end{array}$ \\
\hline Yap/Düş &, 140 & 2 & 319 &, 870 \\
\hline His/Sez & 1,265 & 2 & 319 &, 284 \\
\hline Gör/İşit &, 259 & 2 & 319 &, 772 \\
\hline Sıra/Büt & 1,154 & 2 & 319 &, 317 \\
\hline
\end{tabular}

Tablo 23'ten görüleceği gibi Levene testi sonucunda öğrenme stilleri alt boyutlarının tamamında grup varyansları eşit olarak tespit edilmiştir (p>.05). Dolayısıyla ANOVA'nın ön koşulu sağlanmıştır.

Öğretmen adaylarının öğrenme stilleri alt boyutlarına ilişkin anne çalışma durumuna göre ANOVA testi sonuçları Tablo 24'te sunulmuştur. 
Tablo 24. Öğrenme stilleri alt boyutlarının öğretmen adaylarının anne çalışma durumuna göre karşılaştırılmasına ilişkin tek yönlü varyans analizi (ANOVA) sonuçları

\begin{tabular}{|c|c|c|c|c|c|c|}
\hline $\begin{array}{c}\text { Öğrenme Stilleri } \\
\text { Alt Boyutları }\end{array}$ & $\begin{array}{c}\text { Varyansın } \\
\text { Kaynağı }\end{array}$ & $\begin{array}{c}\text { Kareler } \\
\text { Toplamı } \\
\end{array}$ & $\begin{array}{c}\text { Serbestlik } \\
\text { Derecesi }\end{array}$ & $\begin{array}{c}\text { Kareler } \\
\text { Ortalaması } \\
\end{array}$ & $\mathbf{F}$ & $\mathbf{p}$ \\
\hline \multirow{3}{*}{ Yap/Düş } & Gruplar arası & 19,658 & 2 & 9,829 & \multirow[t]{3}{*}{ 697 } & \multirow[t]{3}{*}{499} \\
\hline & Gruplar içi & 4496,221 & 319 & 14,095 & & \\
\hline & Toplam & 4515,879 & 321 & & & \\
\hline \multirow{3}{*}{ His/Sez } & Gruplar arası & 25,792 & 2 & 12,896 & \multirow[t]{3}{*}{805} & \multirow[t]{3}{*}{ 448 } \\
\hline & Gruplar içi & 5108,444 & 319 & 16,014 & & \\
\hline & Toplam & 5134,236 & 321 & & & \\
\hline \multirow{3}{*}{ Gör/İşit } & Gruplar arası & 50,958 & 2 & 25,479 & \multirow[t]{3}{*}{1,552} & \multirow[t]{3}{*}{,213 } \\
\hline & Gruplar içi & 5235,517 & 319 & 16,412 & & \\
\hline & Toplam & 5286,475 & 321 & & & \\
\hline \multirow{3}{*}{ Sıra/Büt } & Gruplar arası & 35,427 & 2 & 17,713 & \multirow[t]{3}{*}{1,281} & \multirow[t]{3}{*}{,279 } \\
\hline & Gruplar içi & 4410,017 & 319 & 13,825 & & \\
\hline & Toplam & 4445,444 & 321 & & & \\
\hline
\end{tabular}

Öğretmen adaylarının “anne çalışma durumuna” göre karşılaştırılmasına ilişkin öğrenme stilleri alt boyutları bakımından aralarında anlamlı farklılık tespit edilmemiştir.

Öğretmen adaylarının baba çalışma durumuna göre öğrenme stilleri betimsel istatistikleri Tablo 25'te sunulmuştur.

Tablo 25. Öğrenme stili alt boyut puanlarının baba çalışma durumuna ilişkin betimsel istatistikleri

\begin{tabular}{|c|c|c|c|c|c|}
\hline Öğrenme Stili Boyutları & Sınıf Düzeyi & $\mathbf{N}$ & Ortalama & Standart Sapma & $\begin{array}{c}\text { Standart } \\
\text { Hata }\end{array}$ \\
\hline \multirow{4}{*}{ Yap/Düş } & Çalışmiyor & 19 & 1,0000 & 4,26875 & ,97932 \\
\hline & Çalışıyor & 237 & 1,0295 & 3,73077 & ,24234 \\
\hline & Emekli & 66 & 1,1818 & 3,72480 & ,45849 \\
\hline & Toplam & 322 & 1,0590 & 3,75075 & ,20902 \\
\hline \multirow{4}{*}{ His/Sez } & Çalışmiyor & 19 & ,7895 & 4,21082 & ,96603 \\
\hline & Çalışıyor & 237 & 2,5949 & 3,93114 & ,25536 \\
\hline & Emekli & 66 & 2,2424 & 4,12892 & ,50824 \\
\hline & Toplam & 322 & 2,4161 & 3,99931 & ,22287 \\
\hline \multirow{4}{*}{ Gör/İşit } & Çalışmıyor & 19 & 3,8421 & 3,00487 & ,68936 \\
\hline & Çalışıyor & 237 & 5,0000 & 4,18330 & ,27173 \\
\hline & Emekli & 66 & 5,5303 & 3,82389 & 47069 \\
\hline & Toplam & 322 & 5,0404 & 4,05817 & 22615 \\
\hline \multirow{4}{*}{ Sira/Büt } & Çalışmiyor & 19 & 2,0526 & 3,67384 & ,84284 \\
\hline & Çalışıyor & 237 & 1,6962 & 3,84230 & 24958 \\
\hline & Emekli & 66 & 1,4545 & 3,31050 & 40749 \\
\hline & Toplam & 322 & 1,6677 & 3,72139 & 20738 \\
\hline
\end{tabular}

Öğretmen adaylarının baba çalışma durumuna ilişkin hangi öğrenme stilinin baskın olduğu ve öğrenme stili alt boyutları arasında baba çalışma durumuna göre anlamlı farklılığın olup olmadığının tespiti için tek yönlü varyans analizi yöntemi (ANOVA) 
uygulanmıştır. ANOVA uygulanmadan önce gruplarının varyans eşitliği için Levene testi yapılmıştır. Levene testi istatistik değerleri Tablo 26' da yer almaktadır.

Tablo 26. Öğrenme stili alt boyutu puanlarının grup varyanslarının eşitliği testi

\begin{tabular}{ccccc}
\hline $\begin{array}{c}\text { Öğrenme Stilleri } \\
\text { Boyutları }\end{array}$ & $\begin{array}{c}\text { Levene } \\
\text { İstatistik }\end{array}$ & $\begin{array}{c}\text { Serbestlik } \\
\text { Derecesi 1 }\end{array}$ & $\begin{array}{c}\text { Serbestlik } \\
\text { Derecesi 2 }\end{array}$ & $\begin{array}{c}\text { Anlamlılık } \\
\text { (p) }\end{array}$ \\
\hline Yap/Düş &, 285 & 2 & 319 &, 752 \\
\hline His/Sez &, 587 & 2 & 319 &, 557 \\
\hline Gör/İşit & 1,883 & 2 & 319 &, 154 \\
\hline Sıra/Büt & 1,940 & 2 & 319 &, 145 \\
\hline
\end{tabular}

Tablo 26'dan görüleceği gibi Levene testi sonucunda öğrenme stilleri alt boyutlarının tamamında grup varyansları eşit olarak tespit edilmiştir (p>.05). Dolayısıyla ANOVA'nın ön koşulu sağlanmıştır.

Öğretmen adaylarının öğrenme stilleri alt boyutlarına ilişkin baba çalışma durumuna göre ANOVA testi sonuçları Tablo 27'de sunulmuştur.

Tablo 27. Öğrenme stilleri alt boyutlarının öğretmen adaylarının baba çalışma durumuna göre karşılaştırılmasına ilişkin tek yönlü varyans analizi (ANOVA) sonuçları

\begin{tabular}{|c|c|c|c|c|c|c|}
\hline $\begin{array}{l}\text { Öğrenme Stilleri } \\
\text { Alt Boyutları }\end{array}$ & $\begin{array}{l}\text { Varyansın } \\
\text { Kaynağ1 }\end{array}$ & $\begin{array}{c}\text { Kareler } \\
\text { Toplamı }\end{array}$ & $\begin{array}{c}\text { Serbestlik } \\
\text { Derecesi }\end{array}$ & $\begin{array}{c}\text { Kareler } \\
\text { Ortalamas1 }\end{array}$ & F & $\mathrm{p}$ \\
\hline \multirow{3}{*}{ Yap/Düş } & Gruplar arası & 1,267 & 2 & 634 & \multirow[t]{3}{*}{,045 } & \multirow[t]{3}{*}{,956 } \\
\hline & Gruplar içi & 4514,611 & 319 & 14,152 & & \\
\hline & Toplam & 4515,879 & 321 & & & \\
\hline \multirow{3}{*}{ His/Sez } & Gruplar arası & 59,843 & 2 & 29,921 & \multirow[t]{3}{*}{1,881} & \multirow[t]{3}{*}{ 154 } \\
\hline & Gruplar içi & 5074,393 & 319 & 15,907 & & \\
\hline & Toplam & 5134,236 & 321 & & & \\
\hline \multirow{3}{*}{ Gör/İşit } & Gruplar arası & 43,509 & 2 & 21,755 & \multirow[t]{3}{*}{1,324} & \multirow[t]{3}{*}{,268 } \\
\hline & Gruplar içi & 5242,966 & 319 & 16,436 & & \\
\hline & Toplam & 5286,475 & 321 & & & \\
\hline \multirow{3}{*}{ Sıra/Büt } & Gruplar arası & 6,007 & 2 & 3,003 & \multirow[t]{3}{*}{,216 } & \multirow[t]{3}{*}{806} \\
\hline & Gruplar içi & 4439,438 & 319 & 13,917 & & \\
\hline & Toplam & 4445,444 & 321 & & & \\
\hline
\end{tabular}

${ }^{*} p<.05$

Öğretmen adaylarının "baba çalışma durumuna" göre karşılaştırılmasına ilişkin öğrenme stilleri alt boyutları bakımından aralarında anlamlı farklılık tespit edilmemiştir.

\section{Tartışma, Sonuç ve Öneriler}

Öğretmen adaylarının, Öğrenme Stilleri Envanteri'nden aldıkları puanların ortalamalarına göre öğrenme stilleri değerlendirilmiştir. Bulgular incelendiğinde, Fen Bilimleri öğretmen adayları yaparak, hissederek, görsel ve sıralı öğrenme stiline sahip oldukları tespit edilmiştir. Öğretmen adaylarının aldıkları puanlara göre yaparak, hissederek ve sıralı öğrenme stili zayıf düzey, görsel öğrenme stili ise orta düzey olarak değerlendirilmiştir. Ayrıca öğretmen adaylarının yaparak, hissederek ve sıralı öğrenme stili düzeyleri zayıf düzeyde olması onların düşünerek, sezgisel ve bütünsel öğrenme stillerinin de diğer öğrenme 
stillerine yakın değerde var olduğunu göstermektedir. Şeker Sır ve arkadaşlarının (2015) yaptığı çalışmada öğretmen adaylarının yansıtan, duyumsal, görsel ve bütünsel öğrenme stillerinde yoğunlaştıkları gözlenmiştir. Benzer şekilde, Fer (2003) tarafından gerçekleştirilen araştırma sonucu ile de uyumlu olduğu görülmektedir. Ayrıca Fer (2003) öğretmen adaylarından en duyumsal olanların Fen Bilimleri öğretmen adayları olduklarını tespit etmişlerdir.

Öğretmen adaylarının öğrenme stillerinin cinsiyete göre değişip değişmediği bulgusu incelendiğinde, kadın öğretmen adaylarının erkek öğretmen adaylarına göre hissederek ve görsel öğrenme stillerinin anlamlı derecede farklılık gösterdiği tespit edilmiştir. Ancak, yaparak/düşünerek ve sıralı/bütünsel alt boyut puanları arasında cinsiyet değişkenine göre anlamlı farklılık görülmemiştir. Kadın ve erkek öğretmen adayları aynı öğrenme stillerine sahip olmakla birlikte kadınların hissederek ve görsel öğrenme stilleri erkeklere göre daha belirgin şekilde var olduğu görülmektedir. Kadın ve erkeklerin öğrenme stili boyutlarından aldıkları puanlar incelendiğinde sadece duyumsal/sezgisel boyuttan aldıkları puanlar arasında anlamlı bir fark olduğu görülmektedir (Şeker ve ark., 2015). Bu bulgudan hareketle, cinsiyetin öğrenme stili tercihleri üzerinde görece fazla bir etkisinin bulunmadığı sonucuna ulaşılabilir. Ayrıca, Köse (2010), Yağışan ve Sünbül (2009), Çöğenli (2011), Bahar ve Sülün (2011) ve Demir (2008)'in, cinsiyetin öğrenme stillerini anlamlı olarak etkilemediği sonucuna ulaştıkları araştırmalar ile benzer sonuçlara ulaşılmıştır. Ayrıca Keskin Samancı ve Özer Keskin (2007) yaptıkları araştırmada cinsiyetin öğrenme stillerine bir etkisi olmadığı sonucuna ulaşmışlardır.

Öğretmen adaylarının öğrenme stillerinin sınıf düzeylerine göre karşılaştırılmasına bakıldığında yalnızca "görsel/işitsel" alt boyutunda anlamlı farklılık tespit edilmiştir. Diğer alt boyutlarda sınıf düzeylerine göre anlamlı bir farklılık bulunamamıştır. Gruplar arasında bakıldığında 3. ve 4. sinıfların 1. ve 2. sinıflara göre görsel öğrenme stilleri anlamlı derecede farklılık göstermektedir. Ancak 1. ve 2 sinıflar, 3 ve 4 sinıflar arasında anlamlı bir farklılık bulunamamıştır. Bunun nedeni 1. ve 2 sınıfların kendi arasında, 3. ve 4. sinıfların da kendi arasında daha benzer olduğu söylenebilir. Şeker Sır ve arkadaşları sınıf düzeyine göre katılımcıların aktif/yansıtan ve görsel/sözel alt boyutlarında anlamlı farklılık tespit etmiştir. Köprülü (2004)'ün Felder ve Silverman ölçeğini kullandığı araştırmasında de benzer şekilde sınıf düzeyinin öğrenme stili tercihini anlamlı olarak etkilediği sonucuna ulaşılmıştır. 
Öğretmen adaylarının mezun oldukları lise türüne göre öğrenme stillerine bakıldığında alt boyutlar bakımından aralarında anlamlı farklılık tespit edilmemiştir. Öğretmen adaylarının mezun oldukları lise türlerinin öğrenme stillerine etki etmediği sonucuna ulaşılmıştır. Güneş ve Gökçek (2012)'in yaptıkları bir araştırmada öğrenme stilleri ile öğrencilerin mezun oldukları alanları arasında anlamlı bir farklılaşma bulunmamıştır.

Öğretmen adaylarının okul öncesi eğitim alma duruma göre öğrenme stillerine bakıldığında alt boyut puanları arasında anlamlı farklılık tespit edilmemiştir. Okul öncesi eğitim alma ya da okul öncesi eğitim almama durumu öğretmen adaylarının öğrenme stillerini etkilememektedir.

Öğretmen adaylarının kaldıkları barınma yerlerine göre öğrenme stilleri arasında anlamlı bir farklılık tespit edilmemiştir. Evde ya da yurtta kalan öğretmen adaylarının öğrenme stilleri birbirinden anlamlı derecede farklı değildir. Yaşadıkları ve kaldıkları ortamlar öğrenme stilleri açısından öğretmen adaylarını etkilememektedir.

Öğretmen adaylarının anne ve baba eğitim durumuna göre öğrenme stilleri alt boyutları bakımından karşılaştırıldığında anne eğitim durumu açısında farklılık bulunmazken baba eğitim durumlarına göre yalnızca görsel/işitsel alt boyutları arasında anlamlı bir farklılık tespit edilmiştir. Öğretmen adaylarının öğrenme stillerinde babalarının eğitim durumlarının, annelerininkilere göre daha etkileyici bir faktör olduğu tespit edilmiştir.

Öğretmen adaylarının hem anne ve hem de baba çalışma durumlarına göre öğrenme stilleri alt boyutları bakımından aralarında anlamlı farklılık tespit edilmemiştir. Öğretmen adaylarının, anne ve babalarının çalışma, emekli veya çalışmama durumları öğrenme stillerini anlamlı derecede etkilemediği görülmektedir.

Araştırmada elde edilen sonuçlara yönelik olarak aşağıdaki öneriler verilebilir.

- Fen Bilgisi öğretmen adaylarının çalışmada tespit edilen öğrenme stillerinin alt boyutların farklılıkları göz önünde bulundurularak öğrenme ortamları düzenlenebilir.

- Öğretmen adaylarının öğrenme stillerine etki eden birçok farklı faktör bulunmaktadır. Bu çalışmada da bazı faktörlerin etkisine bakılmıştır. Bu faktörlerden farklı olan demografik özelliklere göre öğrenme stilleri tespit edilebilir.

- Fen Bilgisi öğretmen adaylarının öğrenme stillerini tespit edilebileceği farklı bölge ve şehirlerde daha büyük örneklem grubu ile çalışılarak araştırma yapılabilir. 


\section{Kaynaklar}

Babadoğan, C. (2000). Öğretim stili odaklı ders tasarımı geliştirme. Milli Ĕ̆itim, 147, 61-63.

Bahar, H. H. \& Sülün, A. (2011). Fen bilgisi öğretmen adaylarının öğrenme stilleri, cinsiyet öğrenme stili ilişkisi ve öğrenme stiline göre akademik başarı. Kastamonu Eğitim Dergisi, 19(2), 379-386.

Büyüköztürk, Ş. (2011). Sosyal Bilimler İçin Veri Analizi El Kitabı (14. baskı). Ankara: Pegem Akademi.

Demir, T. (2008). Türkçe eğitimi bölümü öğrencilerinin öğrenme stilleri ve bunların çeşitli değişkenlerle ilişkisi (Gazi Üniversitesi örneği), Uluslararası Sosyal Araştırmalar Dergisi, 1(4), 129-148.

Dunn, K. \& Dunn, R. (1986). The look of learning styles. Early Years, 8, 46-52.

Durmuş, B., Yurtkoru E. S. \& Çinko, M. (2011). Sosyal Bilimlerde spss'le Veri Analizi. İstanbul: Beta Yay.

Dwyer, J. (1996). Learning differences and teaching styles. Erişim tarihi: 17 Ocak 2017, http://www.yorku.ca/admin/cst/learndifs.html.

Ekici, G. (2001). Öğrenme stiline dayalı biyoloji öğretiminin analizi. Yayınlanmamış Doktora Tezi, Ankara: Gazi Üniversitesi, Eğitim Bilimleri Enstitüsü.

Erden, M. \& Altun, S. (2006). Öğrenme stilleri. İstanbul: Morpa Yayıncılık.

Felder, R. M. \& Henriques, E. R. (1995). Learning and teaching styles in foreing and second language education. Foreign Language Annals, 28(1), 21-31.

Felder, R. M. \& Silverman, L. (1988). Learning and teaching styles in engineering education. Engineering Education, 78(7), 674-681.

Felder, R. M. \& Soloman, B. A. (1994). Index of learning styles. Erişim tarihi: 10 Aralık 2016, http://www.ncsu.edu/felder- public/ILSpage.html

Fer, S. (2003). Matematik, fizik ve kimya öğretmenliği öğrencilerinin öğrenme biçemlerine göre kolay öğrendikleri öğrenme etkinlikleri, Çă̆gdaş Ĕ̆itim, 28(304), 33-43.

Gündoğan Çögenli, A. (2011). Sinıf öğretmenlerinin sahip oldukları öğrenme stilleri ve kullandıkları bilişüstü öğrenme stratejileri. Yayınlanmamış Yüksek lisans tezi, Eskişehir: Anadolu Üniversitesi, Eğitim Bilimleri Enstitüsü.

Güneş, G. \& Gökçek, T. (2012). Learnig styles of pedagogical formation students. Journal of Research in Education and Teaching, 1(4), 28-40.

Güven, M. (2004). Öğrenme stilleri ile öğrenme stratejileri arasındaki ilişki. Yayınlanmamış Doktora Tezi, Eskişehir: Anadolu Üniversitesi Eğitim Bilimleri Enstitüsü.

Karasar, N. (2006). Bilimsel araştırma yöntemleri. Ankara: Nobel Yayın Dağıtım.

Kaya, H. \& Akçin, E. (2002). Öğrenme biçemleri/stilleri ve hemşirelik eğitimi. Cumhuriyet Üniversitesi Hemşirelik Yüksek Okulu Dergisi, 6(2), 31-36.

Kayri, M. (2009). Araştırmalarda gruplar arası farkın belirlenmesine yönelik çoklu karşılaştırma (post-hoc) teknikleri. Fırat Üniversitesi Sosyal Bilimler Dergisi, 19(1), 5164. 
Kılıç, E. \& Karadeniz, Ş. (2004). Cinsiyet ve öğrenme stilinin gezinme stratejisi ve başarıya etkisi. Gazi Ĕ̆itim Fakültesi Dergisi, 24(3), 129-146.

Köprülü, Ö. (2004). Bazı eğitim fakültelerinin İngilizce öğretmenliği bölümünde okuyan öğrencilerin öğrenme stillerinin yabancı dil öğrenimi ve öğretimi ile ilişkisi. Yayınlanmamış Doktora Tezi, İzmir: Dokuz Eylül Üniversitesi, Eğitim Bilimleri Enstitüsü.

Köse, A. (2010). Fen bilgisi öğretmen adaylarının öğrenme stilleri, ders çalışma stratejileri ile Fen Biloisi öğretimi öz yeterlik inançları arasındaki ilişki (ÇOMÜ Örneği). Yayınlanmamış Yüksek Lisans Tezi, Çanakkale: Sosyal Bilimler Enstitüsü.

Mumford, A. (1987). Learning styles and learning. Personnel Review, 16(3), 20-23.

Peker, M., Mirasyedioğlu, Ş. \& Aydın, B. (2004). Matematik öğretmenlerinin dikkate alabilecekleri öğrenme stilleri: McCarthy modeli. Milli Ĕgitim, 163, 72-81.

Samancı, N. K. \& Keskin, M. Ö. (2007). Felder ve Soloman Öğrenme Stili İndeksi: Türkçeye uyarlanması ve geçerlik-güvenirlik çalışması. KEFAD, 8(2), 37-54.

Şeker Sır, N. Ş., Karataş, H. \& Çeliköz, N. (2015). An investigation on the learning style preferences of pre-service teachers. Education Sciences, 10(4), 237-252.

Schunk, D. H. (2009). Bilişsel stil. D. H. Schunk içinde, Eğitimsel bir bakışla öğrenme teorileri (M. Şahin, 5. Baskıdan Çev.), Ankara: Nobel Yayın Dağıtım.

Yağışan, N. \& Sünbül, A.M. (2009). Güzel sanatlar eğitimi bölümü öğrencilerinin öğrenme tercihleri. 8. Ulusal Müzik Eğitimi Sempozyumu, Samsun, 23-25 Eylül 2009.

Yılmaz, A. ve Özgür, S. D. (2012). Türetimci çoklu ortamın öğretmen adaylarının öğrenme stillerine göre başarı, tutum ve kalıcılığa etkisi. Hacettepe Üniversitesi Ĕ̆itim Fakültesi Dergisi, 42, 441-452. 